Full reference: AlHares, A, Elamer, A.A., Alshbili, I \& Moustafa, M, W. (2019) 'Board

\title{
Board Structure and Corporate R\&D Intensity: Evidence from Forbes Global 2000
}

\author{
Aws AlHares \\ Department of Accountancy and Finance, Business School, University of Huddersfield, UK, and \\ Faculty of School of Business Studies, College of the North Atlantic in Qatar, Qatar \\ Email: aalhares@yahoo.co.uk
}

\begin{abstract}
Ahmed A. Elamer *
Brunel Business School, Brunel University London, Kingston Lane, Uxbridge, London, UB8 3PH $\mathrm{UK}$; and

Department of Accounting, Faculty of Commerce, Mansoura University, Mansoura, Egypt

Email: ahmed.a.elamer@gmail.com

*Corresponding author

Ibrahem Alshbili

Consultant at the Libyan Audit Bureau

Email: abrhem200615@yahoo.com
\end{abstract}

\begin{abstract}
Maha W. Moustafa
School of Mathematics and Statistics, The Open University, UK; and Department of Applied Statistics \& Insurance, Mansoura University, Egypt

Email: Maha.Moustafa@open.ac.uk
\end{abstract}

${ }^{*}$ Corresponding author: Brunel Business School, Brunel University London, Kingston Lane, London UB8 3PH, UK, E-mail: ahmed.elamer@brunel.ac.uk or/and ahmed.a.elamer@gmail.com. 


\title{
Board Structure and Corporate R\&D Intensity: Evidence from Forbes Global 2000
}

\begin{abstract}
Purpose - This study seeks to examine the impact of board structure on risk-taking measured by R\&D intensity in OECD countries.

Design/methodology/approach - The study uses a panel data of 200 companies on Forbes Global 2000 over the 2010- 2014 period. It employs the ordinary least square multiple regression analysis technique to examine the hypotheses.

Findings - The results show that the frequency of board meetings and board size are significantly and negatively related to risk-taking measured by R\&D intensity, with a greater significance among Anglo American countries than among Continental European countries. The rationale for this is that the legal and accounting systems in the Anglo-American countries have greater protection through greater emphasis on compliance and disclosure and therefore allowing for less risk-taking.
\end{abstract}

Research limitations/ implications - The results suggest that better-governed firms at firmor national-level have a high expectancy of less risk-taking. These results offer regulators a resilient incentive to pursue corporate governance and disclosure reforms officially and mutually with national-level governance. Thus, these results show the monitoring and legitimacy benefits of governance, resulting in less risk-taking. Lastly, the findings offer investors the opportunity to build specific expectations about risk-taking behavior in terms of $\mathrm{R} \& \mathrm{D}$ intensity in OECD countries. Future research could investigate risk-taking using different arrangement, conducting face-to-face meetings with the firm's directors and shareholders.

Originality / value - This study extends, as well as contributes to the extant CG literature, by offering new evidence on the effect of board structure on risk-taking. The findings will help policymakers in different countries in estimating the sufficiency of the available CG reforms to prevent management mishandle and disgrace.

Keywords: R\&D, Corporate Governance; OECD Countries; Frequency of Board Meetings; Board Size; Forbes 


\section{Introduction}

This study examines the impact of internal corporate governance (CG) mechanism on risktaking during the period 2010 to 2014 in OECD countries. Different country characteristics extend a major degree of influence on the different systems of corporate governance (CG) under which firms execute. Different legal systems impact the quality of the corporate rights that firms must meet. Legal systems are significant because of the serious external controls that they extend on firms dealing with them (Adel et al., 2019; Alshbili \& Elamer, 2019; Elamer et al., 2018, 2019a, b; Elmagrhi et al., 2017; Hassan et al., 2019; Nish, 2015; Ullah et al., 2019; Yu \& Wang, 2018). Thus, this study contributes to current research by analysing how CG mechanisms are mightily determined by certain countries in which firms operate, and how CG mechanisms that are set to be useful in these countries are based on legal, accounting and auditing practices as well as on ownership issues that are combined in those countries. On the other hand, culture impacts attitudes and corporate values in different firms (AlHares and Ntim, 2017).

The literature on the relationship between frequency of board meetings, board size and firm performance, particularly with respect to risk-taking, is not conclusive. For example, previous research is inconclusive on whether board monitoring positively (e.g., Kor, 2006) or negatively (e.g. AlHares et al., 2018; Deutsch, 2005, Yoo and Sung, 2015) impacts firms' R\&D intensity. More specifically, there is a dearth of studies on how different corporate governance mechanisms used by companies influence the risk-taking (Switzer \& Wang, 2013; Matthies, 2013; Tran, 2014). Consequently, this study seeks to contribute to the extant literature by addressing the limitations of previous studies via an empirical examination of the relationship between corporate governance and risk-taking. According to Vafeas (1999), some believe that frequent board meetings and board size would ultimately have a positive impact on a firm's risk-taking, but another view holds that board meetings and board size do not benefit shareholders of a firm. However, there appears to be more support for board structure benefitting forecasts of management earnings (Karamanou and Vafeas, 2005). Another study shows that board structure contributes to improved firm performance (Mangena and Tauringana, 2006). Also, Yu and Wang (2018) suggest that firms with comparatively robust corporate governance instruments, stakeholders tend to have more correct beliefs about firms' future performance, less asymmetry, and investor expectations about earnings change more slickly over the year. This implies that corporate governance performs a significant part in the 
expectedness of firm's future performance and, thus, advances the financial environment (Agyemang-Mintah and Schadewitz, 2019; Ko et al., 2019; Sial et al., 2019; Ullah et al., 2019; Waresul Karim et al., 2013; Zouari and Zouari-Hadiji, 2014).

Extant research offers inconclusive evidence on the association between board of directors and decisions regarding R\&D intensity (Bravo and Reguera-Alvarado, 2017; Chen, 2013, 2014; Dalziel et al., 2011; Tseng et al., 2013). Previous research shows that the level of R\&D intensity is valued for firms, regardless of the industry (Bravo and Reguera-Alvarado, 2017; Eihe and Olive, 2010). Several studies suggest that R\&D activities are highly risky with their returns being highly uncertain (Pindado et al., 2015), and thus, the question of how board of directors' characteristics may influence $R \& D$ choices within a company is a significant issue in the research related to both corporate governance and $R \& D$. This study contributes to the current literature (Bravo and Reguera-Alvarado, 2017; Chen, 2014) by theoretically integrating both agency theory and resource dependence theory by investigating the possible relation between two directors' characteristics board size and board meetings and strategic choices re R\&D intensity. This sheds light on the impact of board of directors characteristics on the application of R\&D plans by in view of both resource agency theory and dependence theory. Our theoretical basis suggests that only directors with adequate resources can make risky and puzzling decisions and encourage $\mathrm{R} \& \mathrm{D}$ plans. Though, these plans are complex and need a great deal of participation. So, the board of directors need to completely extend their monitoring activity to endorse and support these plans (Ben-Amar et al., 2013; Bravo and Reguera-Alvarado, 2017).

Countries in the OECD differ with respect to their legal, accounting and auditing practices, as well as ownership and debt issues. The two major legal systems operating among nations in the OECD provide firms with different legal rights-based respectively on the common law system, as in the US and the UK, and the civil law or code law system, as in Germany and France (Radebaugh et al., 2006). While the common law system offers protection to small individual shareholders, the civil law system provides excellent protection for large institutional shareholders (Radebaugh et al., 2006). The critical differences between the two legal systems are the rights and remedies they afford shareholders. Risk-taking, therefore, respond differently in the countries using the two major legal systems.

Risk-taking is an essential concept because it affects performance, and how a firm deals with risk-taking through its corporate governance mechanisms also affects its shareholders and debt holders. Weak governance can lead to more significant financing costs for higher debt. 
This necessitates shareholders and debt stakeholders being knowledgeable about the rules pertaining to governance in the firm as well as in the country in which they are invested. It is, therefore, in the interests of shareholders and debt stakeholders to know that the companies in which they invest have good monitoring systems that ensure that management is truly representing their interests.

It is predictable in this paper that what impact $C G$ would impact $R \& D$. The question to be raised in this study is, how does board structure moderate the assessment of R\&D in firms?

All firms used in this study are listed in the World's Biggest Public Companies listing, Forbes Global 2000 Leading Companies (Forbes, 2000). The sample is made up of 200 firms from 10 OECD countries. The results show a negative and statistically significant relationship among frequency of board meetings, board size and risk-taking as measured by the intensity of $\mathrm{R} \& \mathrm{D}$ in the firms. The result is consistent with those of prior literature. Moreover, firms in different countries show a negative relationship between frequency of board meetings, board size and risk-taking, but that this relationship is shown to be much smaller in the Continental European countries than in the Anglo-American countries. The rationale for this seems to be that in the Anglo-American countries, the accounting and legal systems in the Anglo-American system has greater protection through greater CG and heavy emphasis is placed on compliance and disclosure and therefore allowing for less risk-taking.

This study contributes to extant research on board of directors features and R\&D intensity by emphasising that both agency theory and resource dependence theory should be cogitated to know the influence of board size and board meetings in mitigating risk-taking measured by R\&D intensity. We theoretically suggest and empirically show that the board size and board meetings negatively affect risk-taking measured by R\&D intensity. The integration of both theories helps to well understand the role of board size and board meetings in $R \& D$ choices. We extend previous research by AlHares et al. (2018), who examined the impact of ownership structure on R\&D intensity. We add to this research by examining additionally the impact of board of directors characteristics on R\&D intensity. Thus, our findings will help policymakers in different countries in estimating the sufficiency of the available CG reforms to prevent management mishandle and disgrace.

The rest of the paper is structured as follows. The next section provides a brief overview of our multi-theoretical framework. The following section presents the literature review and 
hypotheses development. The remaining sections outline the research design, report empirical analyses and provide a conclusion.

\section{Multi Theoretical Framework}

The theories that can be used to discuss this relation between board structure and risk-taking is agency theory, which shows the importance of looking after the interests of shareholders and promoting firm performance; and resource dependence theory, since the board serves as a resource, improving firm value; More frequent meetings and board size may help give the impression that the firm has a board that is actively working.

\subsection{Agency theory}

Garmaise and Liu point to the fact that managers of organisations under the agency theory are prone to investment, even when there is an indication that conditions may not be ideal. Dishonest managers would expose the organisation to systemic risks by taking chances and investing when there are indications that this may not be the best decision. In these instances, dishonest or corrupt managers are generally looking out for their own self-interest.

From an agency perspective, information asymmetry inherits in $R \& D$ make considerable agency costs. $R \& D$ projects are inclined to adverse selection since managers are usually better informed regarding a project's specific features, its value, and probability to succeed (AlHares et al., 2018). In contrast, shareholders might be often misguided by the ambiguous disclosure because signaling costs are high (i.e., leak of important technological information through disclosure may passes down the competitive advantage to the hands of its possible competitors (Rapp and Udoieva, 2017). Also, shareholders cannot evaluate the reasons behind management's behavior who may want to use specific investments to enhance there own market value and human capital returns.

$\mathrm{R} \& \mathrm{D}$ intensity is widely employed as a proxy of risk-taking in business research (AlHares et al., 2018; Elmagrhi et al., 2017) as they have costs. First, intensifying R\&D involves a greater risk of bankruptcy (De Massis et al., 2018). Second, as R\&D intensity reduces the amount of resources unreservedly accessible to managers, it is likely to consider as limiting managers discretion. Third, increasing $R \& D$ investments often requires increase leverage or seeking external fund, which may sequentially force managers to reveal strategic information to outside professionals with the technical background and experience required to administer such activities (Gómez-Mejía et al., 2010). 
But another risk to the agency theory comes from the stakeholder perspective, which sees risk as associated with the failure of corporate governance to take into consideration the interests of all stakeholders (Letza et al., 2004). The risks for the other stakeholders would be greater if corporate governance does not insist on all stakeholders and not just shareholders. Agency theory suggests that board of directors should also monitor plans and/or strategies implementation to hinder managers from performing opportunistically to the detriment of shareholders (Bravo and Reguera-Alvarado, 2017; Pugliese et al., 2009). Hence, the board of directors may improve specific strategies that are linked to firm performance, such as the risktaking.

\subsection{Resource dependence theory}

A well-established body of literature shows that R\&D investments imply dealing with ambiguity and firms need to be good at handling the idiosyncratic risk of R\&D investments (AlHares et al., 2018; Rapp and Udoieva, 2017). The challenging task of R\&D investments lie in a number of risk-inflating dimensions such as real uninsurable uncertainty, moral hazard, sunk costs, long open-ended time intervals between expenditures and eventual pay-offs, adverse selection, and sensitivity to fluctuations in a supply of human resources (Bakker 2013; Rapp and Udoieva, 2017).

Resource dependence theory holds that the boards of directors are important to the functioning and performance of the organisation because the expertise and the connections with others in the outside environment that individual board members have helped the organisation in securing resources for the organisation (Letting et al., 2012; Abdullah\& Valentine, 2009). The corporate board and outside directors are therefore seen as important for the promotion of the performance of the organisation. More than that, the board member diversity and the external networks among board members and other organisations are important factors for resource dependence theory (Letting et al., 2012).

From a resource dependency theory perspective, organisations face risks associated with obtaining the needed resources. This theory holds that organisations are constrained by the environment, especially by their situations, but that they could engage in exchanges and transactions that would allow them to overcome these constraints (Chen \& Roberts, 2010). Risk-taking results when there is a lack of skills and knowledge within the organisation in order to carry out its operations successfully. Thus, the board of directors with significant resources are in a brilliant situation to contribute to firm strategy, especially those involving risk-taking 
(Bravo and Reguera-Alvarado, 2017; Pugliese et al., 2009). Specifically, board size and board meetings may contribute to expanding the human and social capital of boards by delivering boards with such information and resources, and deter risk-taking.

\section{Literature Review}

\subsection{Frequency of board meetings and R\&D intensity}

Researchers pass interest on whether the frequency of board meetings is associated with the financial performance of firms. Theoretically, there are questionable viewpoints as to the influence of frequent board meetings on risk-taking. On the one hand, the frequency of board meetings can benefit in decreasing agency conflicts by passing on information to management and agents transparently (Elmagrhi et al., 2017). It was also notified that more frequent board meetings lead to more monitoring of managers, which can improve performance including control R\&D intensity (Bravo and Reguera-Alvarado, 2017; Ntim, 2016; Ntim, 2013; Vafeas, 1999). It was also thought that organised meetings allow directors the chance to explore strategies and to more frequently estimate how managers are accomplishing their objectives (Vafeas, 1999). Mangena and Tauringana (2006) argue that managers receive adequate information about the firm and have the opportunity to address firmly developing problems when they meet frequently. Additionally, more board meetings improve closer bonds among directors (Lipton and Lorsch, 1992).

An opposing view suggests that shareholders do not acquire a lot from board meetings as the goals of these meetings will not be achieved. Frequency of board meetings does not fulfil much since the time that board members spend together does not really involve much actual exchange that is relevant to shareholders. This is because of the amount of routine involved in board meetings (Vafeas, 1999). Lipton and Lorsch (1992) argue that frequent board meetings do not assist shareholders because meetings waste time from management to monitor others.

Specifically, Vafeas (1999) argues that frequent board meetings cost the organisation, in terms of expenses to cover travel, refreshments and other board activities and are spent on routine tasks. This leads us to propose the following hypothesis:

H1: There is no statistically significant relationship between the frequency of board meetings and $R \& D$ intensity 


\subsection{Board Size and R\&D intensity}

Structure of the board is crucial as it gives a share into the capabilities of the board. According to Solomon (2007), a board should be made up of professionals drawn from diverse backgrounds and with expertise that allows board members to complement each other. While the size of the board is definitive, for a large board of directors is believed to be unfavourable according to agency theory (Sonnenfeld, 2002). Minimal board is seen as being seen as more functional and as having the chance to motivate management (Lipton and Lorsch, 1992). As with large board, the CEO of firm can control because of the need for coordination among many board directors (Jensen, 1993). To forego this negative aspect of board size, Lipton and Lorsch (1992) recommend limiting the number of directors on board and thereby preventing social loafing and free riding as some directors would not put out the effort that they could have done in a smaller group.

Several recent studies have investigated the influence of board size on firm strategy. Elmagrhi et al. (2017) suggest that board size has an impact on board involvement in dividend pay-out decisions. Particularly, a number of studies have implied that board size negatively influences strategies on dividend pay-out, disclosure and risk-taking (Alnabsha et al., 2018; Alshbili et al., 2019; Elamer, 2017; Elamer et al., 2018, 2017, 2019a, b; Elmagrhi et al., 2017; Ntim, 2016; Ntim et al., 2012). Regarding the firm performance, Shakir (2008), Yokishawa and Phan (2004) show a negative relationship between board size and firm performance, which reinforced the inference of Jensen (1993). Haniffa and Hudaib (2006) suggested that a large board is seen as less effective in monitoring firms and costly in terms of compensation. However, Al-Matari et al. (2012) found no relation between board size and firm performance using a Kuwaiti sample. Regarding firm risk, Pathan (2009), Cheng (2008), Platt and Platt (2012), and Mathew et al. (2016) find a significant negative association between firm risk and board size. This leads us to propose the following hypothesis:

H2: There is no statistically significant relationship between the board size and $R \& D$ intensity

\section{Research Methodology}

\subsection{Sample and data considerations}

The sample consisted of 200 firms drawn from the OECD countries, 20 firms selected from 10 different countries. All companies selected in this study are listed in the World's Biggest Public Companies listing, Forbes Global 2000 Leading Companies (Forbes, 2000). Two different 
traditions were considered in this study: the Anglo American and Continental European traditions. Countries included in this study from the Anglo tradition are Australia, Canada, Ireland, UK and the US. The remaining 5 countries are France, Germany, Italy, Japan and Spain, which represent the Continental European.

Annual reports are the major source of information in this study and data obtained for the years between 2010 and 2014 from the Perfect Information Database and firms' website.

\subsection{Definition of variables and model specification}

This study examines the influence of internal CG mechanisms, including the frequency of board meetings and board size on firms' risk-taking within the OECD context. The variables used in this study are summarised in table (1). The CG variables were collected from the companies' annual reports, which were obtained from their websites. This study measures firms' risk-taking by calculating the natural logarithm of the percentage of $\mathrm{R} \& \mathrm{D}$ expenditure divided by total sales, which is the most frequently used ratio in prior studies. (Ntim et al., 2018; Honoré, 2015)

Internal $C G$ mechanisms variables include board size $(B Z)$ and frequency of board meetings $(F B M)$. Control variables include sales growth $(S G)$, firm's size $(F S)$, audit committee (AC NO), corporate governance committee $(C G C N O)$, leverage $(L V G)$, corruption index (CORR IDX), inflation (INFL), gross domestic product per capita $(G D P C)$, population $(P O P)$ and Power Distance (POWD).

\section{INSERT TABLE 1 ABOUT HERE}

Ordinary least squares (OLS) regression would be used to test our hypothesis and the following model is proposed

$$
R T_{i t}=\alpha_{0}+\beta_{1} B_{i t}+\beta_{2} F_{B M}+\sum_{i=1}^{n} \beta_{i} \text { FCONTROLS }_{i t}+\sum_{i=1}^{n} \beta_{i} \text { CCONTROLS }_{i t}+\varepsilon_{i t}
$$

\section{Results}

\subsection{Descriptive analysis and bivariate correlations}

Table 2 shows a summary of the descriptive statistics of the dependent and independent variables. The minimum board size of all firms is (5), while the largest (22) and these are the same statistics for the overall period as well as for each year. This is because the boards that were studied remained the same throughout. The average size for the overall period was (12.23) and this fluctuated only a little over this period with the least being (12.10) in 2006 and the 
greatest being (12.28) in 2012. The minimum number of board meetings was (0) and the maximum was (35) in the overall sample period. The average over the sample period is (8.08) and the standard deviation is (3.957). The findings show that $R \& D / T o t a l$ sales ranges from a minimum of (.000029) to a maximum of (1.094466) with an average of (.045) for the overall sample period of 2010 to 2014 . The standard deviation is (0.96), which does not represent a major range. The mean or average is relatively stable over the period except in 2014, where it is relatively smaller. The standard deviation fluctuates over the period and shows that individual years have different ranges

\section{INSERT TABLE 2 ABOUT HERE}

The results of correlation matrices are demonstrated in table 3. The coefficients of Pearson's and Spearman's are used as a robustness check.

\section{INSERT TABLE 3 ABOUT HERE}

\section{Empirical findings and discussion}

Table 4 shows a statistically significant and negative relationship between the frequency of board meetings and risk-taking measured by $\mathrm{R} \& \mathrm{D} / \mathrm{Sales}$, thereby providing empirical support for H1. This relationship proposes that the more board meetings are held, the lower the risktaking. This relationship is based on the idea that frequent board meetings mean greater monitoring of management. The overall average for all firm years is $\left(-4.286^{* * *}\right)$ for the frequency of board meetings. This finding shows that there is a negative relationship between the frequency of board meetings and risk-taking, significant to $1 \%$. This suggests that when meetings are more frequent, risk-taking will decrease. Board size has been touted as an important factor in the success of a board and in the success of a firm's performance, but others have argued that either size did not matter or else too large a board could be detrimental.

Hypothesis $\mathrm{H} 2$ has been used to show the relationship between board size and risktaking measured by $R \& D / S a l e s$, and states that "there is no statistically significant relationship between the board and R\&D intensity". The findings show that there is a negative relationship. A negative result shows that a strong board has a negative impact on risk-taking, because of protecting the shareholders' interests and keeping management from pursuing their own selfinterests. The theories that are used in explaining this finding are agency theory and resource dependence theory. Consistent with this notion, Cheng (2008) suggests that US companies with bigger boards are related to lower performance volatility. Likewise, Nakano and Nguyen (2012) suggest that firms with larger boards show lower performance volatility as well as lower bankruptcy risk. Similarly, Adams and Ferreira (2010) show that larger groups are less extreme 
in their gambling decisions, while Bar et al. (2005) reveal that team-managed mutual funds are less likely to deviate from their professed investment styles compared to individual managers. Also, our results support Wang (2012), who suggest that larger boards are willing to reject risky policy choices aligned with the shareholders' interest.

According to agency theory, board members protect shareholders' interests through their surveillance of management (Vafeas 1999; Mangena and Tauringana, 2006). This finding supports studies, including Karamanou and Vafeas (2005), who show that among 275 U.S. listed companies, frequent board meetings had a positive effect. However, another view is that more frequent boards meetings result in higher costs for boards and firms, eventually leading to poor performance. The theories that can be used to discuss this relationship between frequency of board meetings and risk-taking is agency theory, which shows the importance of looking after the interests of shareholders and promoting firm performance; and resource dependence theory, since the board serves as a resource, improving firm value. More frequent meetings may help give the impression that the firm has a board that is actively working. Our results are consistent with previous research. For instance, Battaglia and Gallo (2017) find that firms with lower frequency of board meetings per year confront more severe losses than other firms.

Firm size is also significant, but at 5\% and negative. Firm size mattered as firms of different sizes had different CG structures. Differences in firm size affected risk-taking. In terms of audit committees, here was also a negative relationship, significant at $10 \%$. This meant that an increase in the audit committee led to a reduction in risk-taking. Significance to CG committee number was $\left(5.126^{* * *}\right)$ significant at $1 \%$. This suggests that when $\mathrm{CG}$ increases, so does the likelihood of investment in R\&D (Black et al., 2010). Audit committees would lead to an increase in the creditworthiness of the company, as these committees carry out more surveillance of firms, leading to better protection of shareholders' interests (AlHares et al., 2018; Lai \& Chen, 2014).

With the country variables, Anglo-American corruption index and power distance have relations with risk-taking that are significant at $1 \%$. Corruption index, power distance and Anglo-American have a positive relationship. The findings are $\left(2.005^{* *}\right)$ for corruption index, $(3.493 * * *)$ for power distance and (4.578***) for Anglo-American. An increase in corruption index and power distance led to increase in risk-taking. The positive significance of AngloAmerican means that firms from Anglo countries perform better in terms of risk-taking than firms from Continental countries. This reflects the fact that the Anglo-American system leads 
to a decline in risk and, ultimately, in credit risk. According to research, since the AngloAmerican tradition has rigid CG mechanisms established by country practices, heavy emphasis is placed on compliance and disclosure, leading to reduced risk-taking (Jenkinson and Mayer, 2012).

\section{Conclusions}

\section{INSERT TABLE 4 ABOUT HERE}

The study examines the impact of internal CG mechanisms on companies' risk-taking during the period 2010 to 2014 in OECD. The results show a negative and statistically significant relationship among frequency of board meetings, board size and risk-taking as measured by the intensity of $R \& D$ in the firms. The result is consistent with those of prior literature.

Moreover, firms in different countries show a negative relationship between frequency of board meetings, board size and risk-taking, but that this relationship is shown to be much smaller in the Continental European countries than in the Anglo-American countries. The rationale for this seems to be that in the Anglo-American countries, the accounting and legal systems in the Anglo-American system has greater protection through greater CG and heavy emphasis is placed on compliance and disclosure and therefore allowing for less risk-taking.

Frequency of board meetings is significant and negative. This supports the position that the more often board meetings are held, the less risk there is. The literature shows that frequent meetings can lead to a reduction in risk (Karamanou and Vafeas, 2005). This may be because more frequent board meetings mean more monitoring of management, thereby reducing risktaking (Vafeas, 1999). This is based on the idea that there is more strategising at board meetings, thereby promoting more creative solutions to problems (Vafeas, 1999). Frequent board meetings were also thought to be effective in promoting closer ties between members (Lipton and Lorsch, 1992). But Vafeas (1999) suggests that the argument can be made that more frequent board meetings do not help, because more costs are associated with holding these meetings.

This study has contributed to existing research by investigating the relationship between CG mechanisms and companies' risk-taking, which has rarely been addressed by previous studies. Our paper improves the relation between agency theory and resource dependence theory by suggesting that board size and board meetings mitigate risk taking measured by $R \& D$ intensity, nevertheless only if board of directors can achieve their monitoring activity effectively. Empirical results suggest that board size can create benefits and affect corporate risk-taking strategy because of the skills, networks and/or knowledge, which they obtain in the boards that they sit on. Though, a high number of director's post make 
boards 'too busy' to control and take initiatives re risk taking. Furthermore, given the recent focus on the issues of board structure both in academia and amongst policymakers, our results are timely and add to the argument on the benefits and costs of these board of directors' features. Concerning the R\&D and risk management field, this study suggests advice to managers and policymakers about the selection procedure of board members who can have an important effect on risk taking measured by $R \& D$ intensity. Lastly, our results highlight the need for the deliberation of both agency theory and resource dependence theory so as to advance theoretical frameworks that can better elucidate the role of board of directors in risk taking literature.

Despite the contributions presented above, this research has potential limitations that should be taken into consideration. The first possible limitation is associated with the sample. This research depends only on companies listed in Forbes Global 2000. This study offers new possibilities for future research in a number of ways. First, future studies may consider other markets such as China and India. Another avenue would be to use other measures of risktaking. Finally collecting primary data such as interviews may enrich future research. 


\section{References}

Abdioglu, N., Bamiatzi, V., Cavusgil, S. T., Khurshed, A., \& Stathopoulos, K. (2015). Information asymmetry, disclosure and foreign institutional investment: An empirical investigation of the impact of the Sarbanes-Oxley Act. International Business Review, 24(5), 902-915.

Abdullah, H., \& Valentine, B. (2009). Fundamental and ethics theories of corporate governance. Middle Eastern Finance and Economics, 4(4), 88-96.

Adams, R. \& Ferreira, D. 2010. Moderation in groups: Evidence from betting on ice break-ups in Alaska. Review of Economic Studies, 77: 882-913.

Adams, R. B. (2005). What do boards do? Evidence from board committee and director compensation data. Evidence from Board Committee and Director Compensation Data (March 13, 2003). EFA.

Agyemang-Mintah, P., \& Schadewitz, H. (2019). Gender diversity and firm value: evidence from UK financial institutions. International Journal of Accounting \& Information Management, 27(1), 2-26.

AlHares, A. M. (2017). A Cross-Country Study of the Effects of Corporate Governance Mechanisms on RiskTaking, Credit Rating and Cost of Capital (Doctoral dissertation, University of Huddersfield).

AlHares, A., \& Ntim, C. G. (2017). A Cross-country Study of the Effects of Institutional Ownership on Credit Ratings. International Journal of Business and Management, 12(8), 80.

AlHares, A., Ntim, C. G., \& King, D. (2018). Block Ownership and Companies’ R\&D Intensity: The Moderating Effect of Culture. AlHares, A., Ntim, CG, \& King, D.(2018). Block ownership and companies' R\&D intensity: The moderating effect of culture. Corporate Ownership \& Control, 15(2), 19-32.

AlHares, A., Ntim, C., \& King, D. (2018). Block Ownership and Companies' R\&D Intensity: The Moderating Effect Of Culture. Corporate Ownership \& Control, 15(2), 19-32.

AlHares, A., Ntim, C., King, D., \& Byrne, R. (2018). Does ownership structure improve credit ratings?. Journal of Governance and Regulation/Volume, 7(2).

Allegrini, M., \& Greco, G. (2013). Corporate boards, audit committees and voluntary disclosure: Evidence from Italian listed companies. Journal of Management \& Governance, 17(1), 187-216.

Al-Matari, E. M., Al-Swidi, A. K., Fadzil, F. H., \& Al-Matari, Y. A. (2012). The impact of board characteristics on firm performance: Evidence from nonfinancial listed companies in Kuwaiti stock exchange. International Journal of Accounting and Financial Reporting, 2(2), 310.

Alnabsha, A., Abdou, H. A., Ntim, C. G., \& Elamer, A. A. (2018). Corporate boards, ownership structures and corporate disclosures : Evidence from a developing country. Journal of Applied Accounting Research, 19(1), 2041. https://doi.org/10.1108/JAAR-01-2016-0001

Alshbili, I., Elamer, A. A., \& Beddewela, E. (2019). Ownership types, corporate governance and corporate social responsibility disclosures: Empirical evidence from a developing country. Accounting Research Journal, Forthcoming. https://doi.org/10.1108/ARJ-03-2018-0060

Anderson, R. C., Mansi, S. A., \&Reeb, D. M. (2004). Board characteristics, accounting report integrity, and the cost of debt. Journal of Accounting and Economics, 37(3), 315-342.

Arcot, S., Bruno, V., \& Faure-Grimaud, A. (2010). Corporate governance in the UK: Is the comply or explain approach working?.International Review of Law and Economics, 30(2), 193-201.

Bakker, G. 2013. Money for nothing: How firms have financed R\&D-projects since the industrial revolution. Research Policy, 42 (10), 1793-814.

Bar, M., Kempf, A., \& Ruenzi, S. 2005. Team management and mutual funds . Working Paper, Cologne University.

Baranchuk, N., \&Dybvig, P. H. (2009). Consensus in diverse corporate boards. Review of Financial Studies, 22(2), 715-747.

Battaglia, F., \& Gallo, A. (2017). Strong boards, ownership concentration and EU banks' systemic risk-taking: Evidence from the financial crisis. Journal of International Financial Markets, Institutions and Money, 46, 128146. 
Belloc, F. (2012). Corporate governance and innovation: A survey. Journal of Economic Surveys, 26(5), 835-864.

Ben-Amar, W., Francoeur, C., Hafsi, T., and Labelle, R. (2013) What makes better boards? A closer look at diversity and ownership. British Journal of Management, 24, 85-101.

Bianchini, S., Krafft, J., Quatraro, F., \&Ravix, J. (2015). Corporate governance, innovation and firm age: insights and new evidence (No. 201502). University of Turin.

Black, B. S., Kim, W., Jang, H., \& Park, K. S. (2015). How corporate governance affect firm value? Evidence on a self-dealing channel from a natural experiment in Korea. Journal of Banking \& Finance, 51, 131-150.

Boone, A. L., Casares Field, L., Karpoff, J. M., \&Raheja, C. G. (2007). The determinants of corporate board size and composition: An empirical analysis. Journal of Financial Economics, 85(1), 66-101.

Bravo, F., \& Reguera-Alvarado, N. (2017). The effect of board of directors on R\&D intensity: board tenure and multiple directorships. $R \& D$ Management, 47(5), 701-714.

Brennan, N. (2006). Boards of directors and firm performance: is there an expectations gap?.Corporate Governance: An International Review, 14(6), 577-593.

Cai, J., Liu, Y., Qian, Y., \& Yu, M. (2015). Information asymmetry and corporate governance. Quarterly Journal of Finance, 5(03), 1550014.

Chen, H.L. (2013) CEO tenure, independent directors and corporate innovation. Journal of Applied Finance \& Banking, 3, 187-197.

Chen, H.L. (2014) Board capital, CEO power and R\&D investment in electronics firms. Corporate Governance: An International Review, 5, 422-436.

Chen, L. Y., Chen, Y. F., \& Yang, S. Y. (2017). Managerial incentives and R\&D investments: The moderating effect of the directors' and officers' liability insurance. The North American Journal of Economics and Finance, 39, 210-222.

Cheng, S. (2008). Board size and the variability of corporate performance. Journal of financial economics, 87(1), 157-176.

Cheng, S. (2008). Board size and the variability of corporate performance. Journal of Financial Economics, 87(1), $157-176$

Cheng, S. 2008. Board size and the variability of corporate performance. Journal of Financial Economics, 87: $157-176$.

Choi, Y. R., Zahra, S. A., Yoshikawa, T., \& Han, B. H. (2015). Family ownership and R\&D investment: The role of growth opportunities and business group membership. Journal of Business Research, 68(5), 1053-1061.

Conheady, B., McIlkenny, P., Opong, K.K., \&Pignatel, I. (2015). Board effectiveness and firm performance of Canadian listed firms. The British Accounting Review, 47(3), pp. 290-303.

Corbetta, G., \&Salvato, C. A. (2004). The board of directors in family firms: one size fits all? Family Business Review, 17(2), 119-134.

Daily, C. M., Dalton, D. R., \&Cannella, A. A. (2003). Corporate governance: Decades of dialogue and data. Academy of Management Review, 28(3), 371-382.

Dalziel, T., Gentry, R.J., and Bowerman, M. (2011) An integrated agency-resource dependence view of the influence of directors' human and relational capital on firms' R\&D spending. Journal of Management Studies, 48 , 1217-1242.

De Massis, A., Ding, S., Kotlar, J., \& Wu, Z. (2018). Family involvement and R\&D expenses in the context of weak property rights protection: an examination of non-state-owned listed companies in China. The European Journal of Finance, 24(16), 1506-1527.

Decker, C., \&Günther, C. (2017). The impact of family ownership on innovation: evidence from the German machine tool industry. Small Business Economics, 48(1), 199-212.

Deutsch, Y. (2005). The impact of board composition on firms' critical decisions: A meta-analytic review. Journal of Management, 31(3), 424-444. 
Donnelly, R., \&Mulcahy, M. (2008). Board structure, ownership, and voluntary disclosure in Ireland. Corporate Governance: An International Review, 16(5), 416-429.

Driver, C., \&Guedes, M. J. C. (2012). Research and development, cash flow, agency and governance: UK large companies. Research Policy, 41(9), 1565-1577.

Eihe, I.C., and Olive, C. (2010) The effect of R\&D investment on firm value: an examination of US manufacturing and service industries. International Journal Production Economics, 128, 127-135.

Eisenberg, T., Sundgren, S., \& Wells, M. T. (1998). Larger board size and decreasing firm value in small firms. Journal of Financial Economics, 48(1), 35-54.

Elamer, A. A. (2017). Empirical essays on risk disclosures, multi-level governance, credit ratings, and bank value: Evidence from MENA banks (University of Huddersfield). Retrieved from http://eprints.hud.ac.uk/id/eprint/31700

Elamer, A. A., AlHares, A., Ntim, C. G., \& Benyazid, I. (2018). The corporate governance-risk-taking nexus: evidence from insurance companies. International Journal of Ethics and Systems, 34(4), 493-509. https://doi.org/10.1108/IJOES-07-2018-0103

Elamer, A. A., Ntim, C. G., \& Abdou, H. A. (2017). Islamic Governance, National Governance, and Bank Risk Management and Disclosure in MENA Countries. Business \& Society, 000765031774610. https://doi.org/10.1177/0007650317746108

Elamer, A. A., Ntim, C. G., Abdou, H. A., \& Pyke, C. (2019). Sharia supervisory boards, governance structures and operational risk disclosures: Evidence from Islamic banks in MENA countries. Global Finance Journal, 100488. https://doi.org/10.1016/j.gfj.2019.100488

Elamer, A. A., Ntim, C. G., Abdou, H. A., Zalata, A. M., \& Elmagrhi, M. H. (2019). The impact of multi-layer governance on bank risk disclosure in emerging markets: the case of Middle East and North Africa. Accounting Forum, 43(2), 246-281. https://doi.org/10.1080/01559982.2019.1576577

Elmagrhi, M. H., Ntim, C. G., Crossley, R. M., Malagila, J. K., Fosu, S., \& Vu, T. V. (2017). Corporate governance and dividend pay-out policy in UK listed SMEs: The effects of corporate board characteristics. International Journal of Accounting and Information Management, 25(4), 459-483. https://doi.org/10.1108/IJAIM-02-20170020

Forbes (2000). FORBES Global 2000 Leading Companies. www.forbes.com/global2000.

Gamble, A. and Kelly, G. (2001). Shareholder value and the stakeholder debate in the UK. Corporate Governance: An International Perspective, 9(2), 110-117.

Gómez-Mejía, L. R., M. Makri, and M. Larraza-Kintana. 2010. "Diversification Decisions in Family-controlled Firms.” Journal of Management Studies 47 (2): 223-252. doi: 10.1111/j.1467-6486.2009.00889.x

Guest, P. M. (2009). The impact of board size on firm performance: evidence from the UK. The European Journal of Finance, 15(4), 385-404.

Guldiken, O. \&Daendeli, I. S. (2017). Too much of a good thing: Board monitoring and R\&D investments. Journal of Business Research, 69, 2931-2938

Han, J., Bose, I., Hu, N., Qi, B., \& Tian, G. (2015). Does director interlock impact corporate R\&D investment?.Decision Support Systems, 71, 28-36.

Haniffa, R., \& Hudaib, M. (2006). Corporate governance structure and performance of Malaysian listed companies. Journal of Business Finance \& Accounting, 33(7-8), 1034-1062.

Harjoto, M. A., Laksmana, I., \& Yang, Y. W. (2014).Board Diversity and Corporate Risk Taking. Available at SSRN 2412634.

Honoré, F., Munari, F., \& de La Potterie, B. V. P. (2015). Corporate governance practices and companies' R\&D intensity: Evidence from European countries. Research policy, 44(2), 533-543.

http://www.oecd.org/corporate/ca/corporategovernanceprinciples/31557724.pdf

Iatridis, G. E. (2015). Corporate philanthropy in the US stock market: Evidence on corporate governance, value relevance and earnings manipulation. International Review of Financial Analysis, 39, 113-126. 
James, B, E,.\& McGuire, J. B. (2016). Transactional-institutional fit: Corporate governance of R\&D investment in different institutional contexts. Journal of Business Research, 69, 3478-3486.

Jensen, M. C., \&Meckling, W. H. (1976). Theory of the firm: Managerial behavior, agency costs and ownership structure. Journal of financial economics, 3(4), 305-360.

Jiraporn, P., Chatjuthamard, P., Tong, S., \& Kim, Y. S. (2015). Does corporate governance influence corporate risk-taking? Evidence from the Institutional Shareholders Services (ISS). Finance Research Letters, 13, $105-112$.

Judge, W.Q., Witt, M.A., Zattoni, A. et al. (2014). Corporate governance and IPO underpricing in a crossnational sample: A multilevel knowledge-based view. Strategic Management Journal (2014) published online. DOI: $10.1002 /$ smj.2275

Karamanou, I., \&Vafeas, N. (2005). The association between corporate boards, audit committees, and management earnings forecasts: An empirical analysis. Journal of Accounting Research, 43(3), 453-486.

Kiel, G. C., \& Nicholson, G. J. (2003). Board composition and corporate performance: how the Australian experience informs contrasting theories of corporate governance. Corporate Governance: An International Review, 11(3), 189-205.

Kirkpatrick, G. (2004). Improving corporate governance standards: the work of the OECD and the Principles: Organisation for economic cooperation and Development. Available athttp://www.oecd.org/corporate/ca/corporategovernanceprinciples/33655111.pdf

Kirkpatrick, G. (2009). The corporate governance financial crisis. Financial Market Trends.

Ko, C., Lee, P., \& Anandarajan, A. (2019). The impact of operational risk incidents and moderating influence of corporate governance on credit risk and firm performance. International Journal of Accounting \& Information Management, 27(1), 96-110.

Kor, Y. Y. (2006). Direct and interaction effects of top management team and board compositions on R\&D investment strategy. Strategic management journal, 27(11), 1081-1099.

Krenn, M. (2014). Decoupling as a sustainable firm response to pressures for convergence and divergence in corporate governance: The case of codes of good corporate governance. Journal of Management Policy and Practice, 15(4), 103.

Kumar, P., \&Zattoni, A. (2013).Corporate governance, board of directors, and firm performance. Corporate Governance: An International Review, 21(4), 311-313.

La Porta, R., Lopez-de-Silanes, F., \& Shleifer, A. (2008). The economic consequences of legal origins. Journal of Economic Literature, 46(2), 285-332.

Lacetera, N. (2001). Corporate governance and the governance of innovation: The case of pharmaceutical industry. Journal of management and Governance, 5(1), 29-59.

Lai, J. H., \& Chen, L. Y. (2014). The valuation effect of corporate governance on stakeholder wealth: Evidence from strategic alliances. International Review of Economics \& Finance, 32, 117-131.

Lang, William W., and Julapa A. Jagtiani. "The mortgage and financial crises: The role of credit risk management and corporate governance." Atlantic Economic Journal 38.3 (2010): 295-316.

Liao, T. L., \& Lin, W. C. (2017). Corporate governance, product market competition, and the wealth effect of R\&D spending changes. Financial Management, 46(3), 717-742.

Lipton, M., \&Lorsch, J. W. (1992). A modest proposal for improved corporate governance. The Business Lawyer, 59-77.

Mathew, S., Ibrahim, S., \& Archbold, S. (2016). Boards attributes that increase firm risk-evidence from the UK. Corporate Governance, 16(2), 233-258.

Mathisen, G. E., Ogaard, T., \&Marnburg, E. (2013). Women in the boardroom: How do female directors of corporate boards perceive boardroom dynamics?.Journal of Business Ethics, 116(1), 87-97.

McNulty, T., Florackis, C., \&Ormrod, P. (2013). Boards of directors and financial risk during the credit crisis. Corporate Governance: An International Review, 21(1), 58-78.

Munari, F., Oriani, R., \&Sobrero, M. (2010). The effects of owner identity and external governance systems on R\&D investments: A study of Western European firms. Research Policy, 39(8), 1093-1104. 
Nakano, M., \& Nguyen, P. (2012). Board size and corporate risk taking: further evidence from Japan. Corporate Governance: An International Review, 20(4), 369-387.

Nish, T. (2015). Different board structures and R\&D: Evidence from Japanese corporation. Corporate Board: Role, Duties and Composition, 11(2CONT1), 171-181.

Ntim, C. G. (2013). An integrated corporate governance framework and financial performance in South Africanlisted corporations. South African Journal of Economics, 81(3), 373-392.

Ntim, C. G. (2015). Board diversity and organizational valuation: unravelling the effects of ethnicity and gender. Journal of Management \& Governance, 19(1), 167-195.

Ntim, C. G. (2016). Corporate governance, corporate health accounting, and firm value: The case of HIV/AIDS disclosures in Sub-Saharan Africa. The International Journal of Accounting, 51(2), 155-216. https://doi.org/https://doi.org/10.1016/j.intacc.2016.04.006

Ntim, C. G., \&Soobaroyen, T. (2013). Corporate governance and performance in socially responsible corporations: New empirical insights from a Neo-Institutional framework. Corporate Governance: An International Review, 21(5), 468-494.

Ntim, C. G., Lindop, S., \& Thomas, D. A. (2013). Corporate governance and risk reporting in South Africa: A study of corporate risk disclosures in the pre-and post-2007/2008 global financial crisis periods. International Review of Financial Analysis, 30, 363-383.

Ntim, C. G., Opong, K. K., \& Danbolt, J. (2012). The relative value relevance of shareholder versus stakeholder corporate governance disclosure policy reforms in South Africa. Corporate Governance: An International Review, 20(1), 84-105.

Ntim, C. G., Opong, K. K., \&Danbolt, J. (2012). The relative value relevance of shareholder versus stakeholder corporate governance disclosure policy reforms in South Africa. Corporate Governance: An International Review, 20(1), 84-105.

Ntim, C. G., Opong, K. K., \&Danbolt, J. (2015). Board size, corporate regulations and firm valuation in an emerging market: A simultaneous equation approach. International Review of Applied Economics, 29(2), 194220.

Ntim, C. G., Opong, K. K., Danbolt, J., \& Thomas, D. A. (2012). Voluntary corporate governance disclosures by post-apartheid South African corporations. Journal of Applied Accounting Research, 13(2), 122-144.

O’Connor, M., \& Rafferty, M. (2012). Corporate governance and innovation. Journal of Financial and Quantitative Analysis, 47(2), 397-413.

OECD (2004). Principles of Corporate Governance. OECD. Available at

OECD (2014). Risk management and corporate governance. Corporate governance, OECD Publishing. Available at http://www.oecd.org/daf/ca/risk-management-corporate-governance.pdf

OECD. Available at http://www.oecd.org/finance/financial-markets/42229620.pdf

Pathan, S. (2009). Strong boards, CEO power and bank risk-taking. Journal of Banking \& Finance, 33(7), 13401350 .

Pindado, J., Queiroz, V., \& Torre, C. (2015). How do country level governance characteristics impact the relationship between $\mathrm{R} \& \mathrm{D}$ and firm value?.R\&D Management, 45(5), 515-526.

Pindado, J., Queiroz, V., and Torre, C. (2015) How do country-level governance characteristics impact the relationship between R\&D and firm value? $R \& D$ Management, 45, 515-526.

Platt, H., \& Platt, M. (2012). Corporate board attributes and bankruptcy. Journal of Business Research, 65(8), 1139-1143.

Pugliese, A., Bezemer, P., Zattoni, A., Huse, M., Van den Bosch, F.A.J., and Volberda, H.W. (2009) Boards of directors' contribution to strategy: a literature review and research agenda. Corporate Governance: An International Review, 17, 292-306.

Rapp, M. S., \& Udoieva, I. A. (2017). Corporate governance and its impact on R\&D investment in emerging markets. Emerging Markets Finance and Trade, 53(10), 2159-2178. 
Rapp, M. S., \&Udoieva, I. A. (2017). Corporate Governance and Its Impact on R\&D Investment in Emerging Markets. Emerging Markets Finance and Trade, 53(10), 2159-2178.

Sapra, H., Subramanian, A., \& Subramanian, K. V. (2014). Corporate governance and innovation: Theory and evidence. Journal of Financial and Quantitative Analysis, 49(4), 957-1003.

Sariol, A. M., \&Abebe, M. A. (2017). The influence of CEO power on explorative and exploitative organizational innovation. Journal of Business Research, 73, 38-45.

Shakir, R. (2008). Board size, executive directors and property firm performance in Malaysia. Pacific Rim Property Research Journal, 14(1), 66-80.

Sial, M. S., Chunmei, Z., \& Khuong, N. V. (2019). Do female and independent directors explain the two-way relationship between corporate social responsibility and earnings management of Chinese listed firms?. International Journal of Accounting and Information Management, 27(3), 442-460.

Tanaka, T. (2014). Gender diversity in the boards and the pricing of publicly traded corporate debt: evidence from Japan. Applied Financial Economics, 24(4), 247-258.

Tauringana, V, \&Mangena, M. (2006). Complementary narrative commentaries of statutory accounts in annual reports of UK listed companies. Journal of Applied Accounting Research, 8(2), 71-109.

Tsao, S. M., Lin, C. H., \& Chen, V. Y. (2015). Family ownership as a moderator between R\&D investments and CEO compensation. Journal of Business Research, 68(3), 599-606.

Tseng, C., Wu, Z., and Lin, C. (2013) Corporate governance and innovation ability: empirical study of taiwanese electronics manufactures. International Business Research, 6, 70-78.

Ullah, M. S., Muttakin, M. B., \& Khan, A. (2019). Corporate governance and corporate social responsibility disclosures in insurance companies. International Journal of Accounting \& Information Management, 27(2), 284300 .

Upadhyay, A., \& Zeng, H. (2014). Gender and ethnic diversity on boards and corporate information environment. Journal of Business Research, 67(11), 2456-2463.

Upadhyay, A., \&Sriram, R. (2011). Board size, corporate information environment and cost of capital. Journal of Business Finance \& Accounting, 38(9-10), 1238-1261.

Urbinati, A., Franzò, S., De Massis, A., \&Frattini, F. (2017). Innovation in family firms: a review of prior studies and a framework for future research. In Revolution of Innovation Management (pp. 213-246). Palgrave Macmillan UK.

Vafeas, N. (1999). Board meeting frequency and firm performance. Journal of Financial Economics, 53(1), 113142.

Wang, C. J. (2012). Board size and firm risk-taking. Review of Quantitative Finance and Accounting, 38(4), 519542.

Wang, C. J. (2012). Board size and firm risk-taking. Review of Quantitative Finance and Accounting, 38(4), 519-542.

Waresul Karim, A. K. M., van Zijl, T., \& Mollah, S. (2013). Impact of board ownership, CEO-Chair duality and foreign equity participation on auditor quality choice of IPO companies: evidence from an emerging market. International Journal of Accounting \& Information Management, 21(2), 148-169.

Wintoki, M. B., Linck, J. S., \& Netter, J. M. (2012). Endogeneity and the dynamics of internal corporate governance. Journal of Financial Economics, 105(3), 581-606.

Yawson, A. (2006). Evaluating the characteristics of corporate boards associated with layoff decisions. Corporate Governance: An International Review, 14(2), 75-84.

Yermack, D. (1996). Higher market valuation of companies with a small board of directors.Journal of Financial Economics, 40(2), 185-211.

Yoo, T., \& Sung, T. (2015). How outside directors facilitate corporate R\&D investment? Evidence from large Korean firms. Journal of Business Research, 68(6), 1251-1260. 
Yoo, T., \& Sung, T. (2015). How outside directors facilitate corporate R\&D investment? Evidence from large Korean firms. Journal of Business Research, 68(6), 1251-1260.

Yoshikawa, T., Phan, P. H., \& Linton, J. (2004). The relationship between governance structure and risk management approaches in Japanese venture capital firms. Journal of Business Venturing, 19(6), 831-849.

Yu, M., \& Wang, Y. (2018). Firm-specific corporate governance and analysts' earnings forecast characteristics: Evidence from Asian stock markets. International Journal of Accounting \& Information Management, 26(3), 335361.

Zattoni, A., Douglas, T.,\& Judge, W. (2013).Developing corporate governance theory through qualitative research. Corporate Governance: An International Review, 21(2), 119-122.

Zouari, G., \& Zouari-Hadiji, R. (2014). Directors board, R\&D investment and the firm's performance: Evidence from the French case. Corporate Board: Role, Duties \& Composition, 11(1), 107-122. 


\section{Tables}

\section{Table 1 Variables definition and measurement}

\begin{tabular}{|l|l|}
\hline \multicolumn{2}{|l|}{ CG variable (Board Structure) } \\
\hline Board Size & The total number of directors on the board at the end of financial year \\
\hline $\begin{array}{l}\text { Frequency of Board } \\
\text { Meetings }\end{array}$ & $\begin{array}{l}\text { A binary number of one if a firm's board of directors meets at least four times in a financial year, } \\
\text { and zero otherwise. }\end{array}$ \\
\hline Risk-Taking & Natural logarithm of R\&D expenditure /total sales \\
\hline R\&D/Sales & \multicolumn{2}{|l|}{ (Current year's sales- Previous year's sales) /previous year's sales } \\
\hline Control variables & Natural logarithm of the book value of total assets \\
\hline Sales Growth & Number of Audit Committee \\
\hline Audit Committee & Number of CG Committee \\
\hline $\begin{array}{l}\text { Corporate Governance } \\
\text { Committee }\end{array}$ & Total debt /Total assets \\
\hline Leverage & The misuse of public power for private benefit \\
\hline Corruption Index & The average of general level of prices for goods and services is rising \\
\hline Inflation & GDP/ \# of people living in the country \\
\hline $\begin{array}{l}\text { Gross domestic } \\
\text { product per Capita }\end{array}$ & Number of People living \\
\hline Population & $\begin{array}{l}\text { The degree to which the less powerful members of a society accept and expect that power is } \\
\text { distributed unequally }\end{array}$ \\
\hline Power Distance &
\end{tabular}


Table 2 Summary descriptive statistics of the dependent and independent variables

\begin{tabular}{|l|c|c|c|c|c|}
\hline Variables & Mean & Median & Std, Deviation & Minimum & Maximum \\
\hline Independent (Corporate governance (CG)/Board characteristics) variable & \multicolumn{2}{l|}{} \\
\hline BS & 12.23 & 12 & 3.41 & 5 & 22 \\
\hline FBM & 8.08 & 17.5 & 3.957 & 0 & 35 \\
\hline Dependent Variable (Risk-Taking) & .045 & .0235 & .096 & .000029 & 1.09446 \\
\hline R\&D/Sales & .545 \\
\hline
\end{tabular}


Table 3 Pearson's and Spearman's correlation matrices of the variables

\begin{tabular}{|c|c|c|c|c|c|c|c|c|c|c|c|c|c|}
\hline Variable & $B S$ & $F B M$ & $S G$ & FS & $A C N O$ & $\begin{array}{l}C G C \\
N O \\
\end{array}$ & $\begin{array}{l}\text { CORR } \\
\text { IDX } \\
\end{array}$ & INFL & $P O P$ & $L V G$ & $A N G$ & $G D P C$ & POWD \\
\hline$B S$ & 1 & -.133 & -.082 & .445 & .303 & .246 & -.130 & -.333 & .279 & .258 & .222 & -.165 & .111 \\
\hline$F B M$ & -.081 & 1 & .726 & -.116 & .029 & $.081^{* *}$ & $.119^{* * *}$ & -.054 & .075 & $-.069^{* *}$ & $.212^{* * *}$ & $.141^{* * *}$ & $-.103^{* * *}$ \\
\hline$S G$ & -.086 & -.070 & 1 & $-118^{* * * *}$ & $-.108^{* * *}$ & -.475 & .087 & .056 & -.094 & $-.085^{* * *}$ & .085 & .814 & $-.068^{*}$ \\
\hline$F S$ & .442 & $.056^{*}$ & $-.111^{* * *}$ & 1 & $.365^{* * *}$ & $.335^{* * *}$ & .074 & .074 & -.087 & $.209^{* * *}$ & $-.153^{* * *}$ & -.066 & $.322^{* * *}$ \\
\hline$A C N O$ & .289 & $.091^{* * *}$ & $-.105^{* * *}$ & $.308^{* * *}$ & 1 & $.267^{* * *}$ & $.324^{* * *}$ & $.091^{* *}$ & $.187^{* * *}$ & $.111^{* * *}$ & .063 & $.117^{* * *}$ & -.072 \\
\hline$C G C$ & .230 & $.059^{* *}$ & -.098 & $.224^{* * *}$ & $.187^{* * *}$ & 1 & $.299^{* * *}$ & $-.139^{* * *}$ & $-.097^{* * *}$ & .056 & $.357^{* * *}$ & $.328^{* * *}$ & $-.375^{* * *}$ \\
\hline $\begin{array}{l}\text { CORR } \\
\text { IDX } \\
\end{array}$ & -.88 & $.194^{* * *}$ & $.194^{* * *}$ & $-.069^{*}$ & $.322^{* * *}$ & $.421^{* * *}$ & 1 & $.149^{* * *}$ & $-.246^{* * *}$ & $-.174^{* * *}$ & $.499^{* * *}$ & $.619^{* * *}$ & $-.417^{* * *}$ \\
\hline INFL & -.118 & $.065^{*}$ & $.058^{*}$ & -.847 & .082 & $-.154^{*}$ & $.189^{* * *}$ & 1 & .333 & -.085 & $-.092^{* * *}$ & $-.062^{*}$ & $.109^{* * *}$ \\
\hline$P O P$ & .301 & -.086 & $-.109^{* * *}$ & $.234^{* * *}$ & $.189^{* * * *}$ & $-.092^{* * *}$ & $-.309^{* * *}$ & $-.084^{* *}$ & 1 & $.159^{* * *}$ & $-.421^{* * *}$ & $-.491^{* * *}$ & $.519^{* * * *}$ \\
\hline$L V G$ & .266 & $-.076^{* *}$ & $-.105^{* * *}$ & $.191^{* * *}$ & $.103^{* * *}$ & .147 & $-.193^{* * *}$ & -.066 & $.165^{* * *}$ & 1 & $-.155^{* * *}$ & $-.221^{* * *}$ & $.084^{* *}$ \\
\hline$A N G$ & -.118 & $.259^{* * *}$ & $.087^{*}$ & $-.142^{* * *}$ & $.094^{*}$ & $.347^{* * *}$ & $.513^{* * *}$ & $.104^{* * *}$ & $-.438^{* * * *}$ & $-.186^{* * *}$ & 1 & $.685^{* * *}$ & $-.733^{* * *}$ \\
\hline GDPC & -.179 & $.223^{* * *}$ & $.085^{*}$ & $-.063^{* *}$ & $.118^{* * *}$ & $.327^{* * *}$ & $.673^{* * *}$ & -.097 & $-.491^{* * *}$ & $-.232^{* * *}$ & $.724^{* * *}$ & 1 & $-.586^{* * *}$ \\
\hline POWD & .094 & $-.123^{* * *}$ & $-.089^{* * *}$ & $.189^{* * * *}$ & -.745 & $-.345^{* * *}$ & $-.529^{* * * *}$ & .325 & $.506^{* * *}$ & $.068^{* *}$ & $-.634^{* * * *}$ & $-.517^{* * *}$ & 1 \\
\hline
\end{tabular}

Notes: the bottom left half of the table presents Pearson's parametric correlation coefficients, whilst the upper right half of the table presents Spearman's non-parametric correlation coefficients. ${ }^{* *}$ and ${ }^{*}$ denote correlation is significant at the $1 \%$ and $5 \%$ level, respectively. Variables are defined as follows: Board Size (BS), Frequencies of Board Meeting (FBM), Growth (SG), Firm Size (FS), Sales, Audit Committee No. (AC), Corporate Governance Committee No. (CGC NO), Corruption Index (CORR IDX), Inflation (INFL), Population (POP), Leverage (LVG), Anglo American (ANG), GDP per Capita (GDPC) and Power Distance (POWER D). 
Table 4: OLS Regression Results of Frequency of Board Meetings on R\&D Intensity

\begin{tabular}{|c|c|c|c|c|c|c|c|}
\hline & All firm years & 2010 & 2011 & 2012 & 2013 & 2014 & VIF \\
\hline Adjusted $R^{2}$ & .182 & .125 & .119 & .109 & .194 & .231 & - \\
\hline Standard Error & .716 & .679 & .736 & .764 & .741 & .714 & - \\
\hline Durbin- Watson & $.553 * * *$ & 2.131 & 1.942 & 2.061 & 2.206 & 1.831 & - \\
\hline F-Value & .571 & $1.66^{*}$ & $1.646^{*}$ & $1.623 *$ & $2.242 * * *$ & $2.385 * * *$ & - \\
\hline No. of Observations & 504 & 97 & 99 & 105 & 107 & 96 & - \\
\hline Constant & $-3.426 * * *$ & $-2.409 * *$ & $-1.827^{*}$ & -1.129 & .146 & $-1.706^{*}$ & - \\
\hline \multicolumn{8}{|l|}{ Independent Variables } \\
\hline Board Size & $-2.481^{\star \star}$ & $-2.021^{\star *}$ & $-2.270^{\star \star}$ & -1.131 & -1.366 & -1.539 & 2.56 \\
\hline $\begin{array}{l}\text { Frequency of Board } \\
\text { Meetings }\end{array}$ & $-4.286^{* * *}$ & -.371 & $-2.768 * * *$ & $-1.713 *$ & $-1.722 *$ & $-2.655^{* * *}$ & 3.045 \\
\hline \multicolumn{8}{|l|}{ Control Variables } \\
\hline Firm Size & $-2.079 * *$ & -1.175 & -.939 & -.676 & -.313 & -.655 & 2.462 \\
\hline Sales Growth & .362 & -.144 & -.118 & .528 & -.863 & .554 & 1.071 \\
\hline Audit Committee No. & $-1.624 *$ & -.013 & -1.324 & -1.154 & $-2.281 * *$ & -.053 & 1.367 \\
\hline CG Committee No. & $5.126 * * *$ & $2.255^{* * *}$ & $1.866^{*}$ & $1.968^{*}$ & $2.794 * * *$ & $3.013 * * *$ & 1.210 \\
\hline Leverage & .585 & .298 & 1.535 & -.057 & -.372 & .393 & 1.307 \\
\hline Corruption Index & $2.005^{* * *}$ & -1.309 & .289 & 1.261 & -.242 & $2.985 * * *$ & 1.1885 \\
\hline Inflation & -.783 & $1.864^{*}$ & -1.087 & -.866 & $-3.215 * * *$ & -.206 & 1.132 \\
\hline GDP Per Capita & .753 & $2.973^{* * * *}$ & .325 & -1.232 & -.257 & .316 & 1.209 \\
\hline Population & 1.547 & $2.016^{* *}$ & .508 & -.509 & -.355 & $2.466^{* * *}$ & 2.439 \\
\hline Power Distance & $3.493 * * *$ & -1.426 & .981 & 1.395 & -.315 & $2.009 * *$ & 1.452 \\
\hline Anglo American & $4.578 * * *$ & $-2.249 * *$ & -.258 & .188 & $-1.714 *$ & -1.264 & 5.145 \\
\hline 2010 & 1.217 & - & - & - & - & - & 0.211 \\
\hline 2011 & .564 & - & - & - & - & - & 0.406 \\
\hline 2012 & .414 & - & - & - & - & - & 0.542 \\
\hline 2014 & -.513 & - & - & - & - & - & 0.015 \\
\hline
\end{tabular}

Notes: coefficients are in front of parenthesis. ${ }^{* * *},{ }^{* *}$ and ${ }^{*}$ denote $p$-value is significant at the $1 \%, 5 \%$ and $10 \%$ level, respectively. Also, year 2013 are excluded from the regression analyses. It is used as base year, respectively, for purposes of comparison. 